\title{
Detection of brucellosis in cattle and evaluation of risk factors associated with the
}

\section{disease in workers slaughterhouse}

\author{
Detecção de brucelose em bovinos e avaliação de fatores de risco associados a dloença em \\ trabalhadores de frigorífico
}

Detección de brucelosis en ganado y evaluación de factores de riesgo asociados a enfermedad en trabajadores de refrigerador

Received: 02/24/2021 | Reviewed: 03/03/2021 | Accept: 03/13/2021 | Published: 03/20/2021

Thaise Marques Alves
ORCID: https://orcid.org/0000-0002-0934-530X
Universidade Estadual de Santa Cruz, Brazil
E-mail: thaisemarquesalves@ @mail.com
Poliana de Castro Melo
ORCID: https://orcid.org/0000-0003-0774-6211
Universidade Estadual de Santa Cruz, Brazil
E-mail: policamello@yahoo.com.br
Lilia Marcia Paulin Silva
ORCID: https://orcid.org/0000-0002-0835-8723
Instituto Biológico de São Paulo, Brazil
E-mail: paulin @biologico.sp.gov.br
Nathana Kyolla Santos de Carvalho
ORCID: https://orcid.org/0000-0003-1332-1711
Universidade Estadual de Santa Cruz, Brazil
E-mail: nathannaemanuelly @ hotmail.com
Amora Ferreira Menezes Rios
ORCID: https://orcid.org/0000-0003-3557-2781
Universidade Estadual de Santa Cruz, Brazil
E-mail: amoramenezes@ hotmail.com
Raphaella Barbosa Meirelles Bartoli
ORCID: https://orcid.org/0000-0002-7147-5711
Universidade Federal de Jataí, Brazil
E-mail: raphaella@ ufg.br
Carlos Augusto de Oliveira Júnior
ORCID: https://orcid.org/0000-0002-9609-0746
Universidade Federal do Oeste da Bahia, Brazil
E-mail: carlos.dirgel@ @otmail.com
Henrrique Fernando Santos
ORCID: https://orcid.org/0000-0003-3555-0603
Universidade Estadual de Santa Cruz, Brazil
E-mail: henriqueveterinario@ @otmail.com

\begin{abstract}
Brucellosis is anthropozoonosis caused by Brucella spp. Among the zoonotic species, B. abortus is the main species affecting cattle and can easily be transmitted to humans. The purpose of this study was to investigate, through epidemiological inquiry and serological analysis, animal and human health as related to smooth strain Brucella spp. in a slaughterhouse located in the southern region of the state of Bahia. For this purpose, blood samples were collected from workers and animals at a slaughterhouse together with the State Inspection Service. Then, the Buffered Acidified Plate Antigen test was performed for animals and humans, the Slow Agglutination Test was performed for humans only; and the Complement Fixation Test and the 2-Mercaptoethanol Brucella Agglutination test (2ME) were performed for animals only. In addition, an epidemiological inquiry was applied to workers in order to assess risk factors for the disease. After data analysis, it was concluded that infection by smooth strains of Brucella spp. was detected in $14.0 \%$ of the cattle. Additionally, one worker out 41 tested reactive to the disease.
\end{abstract}

Keywords: Cattle slaughter; Brucella spp.; Butcher; Zoonosis.

\section{Resumo}

A brucelose é uma antropozoonose causada por Brucella spp. Entre as espécies zoonóticas, B. abortus é a mais importante que afeta bovinos e pode ser facilmente transmitida aos seres humanos. O objetivo deste estudo foi 
investigar, a partir de levantamento epidemiológico e análise sorológica, a saúde animal e humana em relação a cepas lisas de Brucella spp. em um matadouro localizado na região sul do estado da Bahia. Para esse fim, foram coletadas amostras de sangue de trabalhadores e animais de um matadouro que possui Serviço de Inspeção Estadual. Em seguida, o teste de antígeno tamponado acidificado foi realizado para animais e humanos; o teste de aglutinação em tubo, foi realizado apenas para humanos; e o teste de fixação do complemento e 2-mercaptoetanol foram realizados apenas em animais. Em adição, foi realizada, pesquisa epidemiológica a partir da aplicação de questionários aos trabalhadores para avaliar os fatores de risco para a doença. Após análise dos dados, concluiu-se que a infecção por cepas lisas de Brucella spp. foi detectada em 14,0\% dos bovinos. Além disso, um trabalhador de 41 funcionários avaliados foi reativo à doença.

Palavras-chave: Abate bovino; Brucella spp., Magarefe; Zoonose.

\section{Resumen}

La brucelosis es una antropozoonosis causada por Brucella spp. Entre las especies zoonóticas, B. abortus es la más importante que afecta al ganado y puede transmitirse fácilmente a los humanos. El objetivo de este estudio fue investigar, a partir de una encuesta epidemiológica y un análisis serológico, la salud animal y humana en relación con cepas lisas de Brucella spp. en un matadero ubicado en la región sur del estado de Bahía. Para ello, se recolectaron muestras de sangre de trabajadores y animales de un matadero que cuenta con Servicio de Inspección del Estado. Luego, se realizó la prueba del antígeno tamponado acidificado para animales y humanos; la prueba de aglutinación en tubo se realizó solo para humanos; y la prueba de fijación del complemento y 2-mercaptoetanol se realizó solo en animales. Además, se realizó una encuesta epidemiológica basada en la aplicación de cuestionarios a los trabajadores para evaluar los factores de riesgo de la enfermedad. Después del análisis de los datos, se concluyó que la infección por cepas lisas de Brucella spp. se detectó en el 14.0\% de los bovinos. Además, un trabajador con 41 empleados evaluados fue reactivo a la enfermedad.

Palabras clave: Sacrificio de ganado; Brucella spp.; Carnicero; Zoonosis.

\section{Introduction}

Bacteria of the genus Brucella spp. are Gram negative coccobacilli, of which an important characteristic for pathogenicity is the fact that they are facultative intracellular (Tortora, 2012) any pathogenic species were described as composing this genus. B. melitensis, B. ovis and B. abortus, are found in ruminants, the latter being more common in cattle (Osterman \& Moriyon, 2006). Swine are affected mainly by B. suis (Emy, 2018) and B. canis is responsible for infection in dogs (Petry, 2019). Other species, such as B. neotomae (desert rat) (Kang, 2019), B. ceti (cetaceans), B. pinnipedialis (pinnipeds) (Jahans, 1997; Scholz, 2008), B. microti (common vole, red fox and wild boar) (Scholz, 2008; Rónai, 2015; Scholz, 2009), B. papionis (baboons) (Whatmore, 2014), afect wild animals. Humans can be infected by B. inopinata (Scholz, 2010) (preferential species) and many species mentioned previously.

The composition of a polysaccharide chain (LPS) of Brucella spp. determines two different antigenic groups. B. melitensis, B. abortus, B. suis, B. neotomae, B. ceti and B. pinnipedialis belong to smooth strains, while B. canis, and B. ovis are in the rough strains group (Osterman \& Moriyon, 2006; Emy, 2018; Petry, 2019; Kang, 2019) Brucella inopinata is informally classified by some researchers as atypical, since its phenotypical characteristics differ from the classic groups of Brucella spp (Zygmunt, 2012).

Smooth strains of Brucella spp. can affect non-specific species. Therefore, the contaminated biological material in pastures and in animal facilities can act as transmission routes for other animals, such as equines, dogs, swine, sheep, goats, and including humans (Osterman \& Moriyon, 2006; Emy, 2018; Petry, 2019; Kang, 2019).

In animals, the clinical signs are mainly related to the reproductive system, such as abortion, infertility, retained placenta and the birth of weak animals. These signs are explained because the bacteria have a preference for these tissues and because the presence of erythritol in testis and pregnant uterus increases bacterial multiplication (Antoniassi, 2017).

Transmission of brucellosis in humans occurs by oral route, through consumption of contaminated products of animal origin, such as milk, dairy products and raw or undercooked meat. Another important route is inhalation, through direct contact with infected animals or secretions and the products of abortion. Transmission can also occur by accidental inoculation of vaccines (Schneider, 2013). As regards occupational health, veterinarians, butchers and livestock professionals, who are in 
constant contact with potentially infected biological material, are at risk for brucellosis (Zigmunt, 2012; Skendros, 2013).

The incubation period for brucellosis in humans varies from 5 to 60 days, but it could even last for up to two years. The clinical signs are nonspecific, they include fever, malaise, sweating (nightly and profusely), chills, lethargy, anorexia, headache, muscle pain, abdominal pain, and, when chronic, the disease most frequently causes joint pain affecting the individual's quality of life (Corbel, 2006).

In Brazil, the serological diagnosis of brucellosis in cattle and buffalo herds is recommended by the National Program of Control and Eradication of Brucellosis and Tuberculosis (Programa Nacional de Controle e Erradicação da Brucelose e Tuberculose Animal - PNCEBT) (Brazil, 2017a). The official tests are the Buffered Acidified Antigen test (RBT), the 2Mercaptoethanol Brucella Agglutination test simultaneously with the Slow Agglutination Test (2ME), the Fluorescence Polarization Assay (FPA), the Complement Fixation Test (CFT), and the Milk Ring Test (MRT), this last one for monitoring dairy herds (Brazil, 2017b).

The laboratorial diagnosis for humans includes the direct test (bacterial culture and PCR) and an indirect test, such as the 2ME, the SAT, the FPA and the Enzyme-Linked Immunosorbent Assay (ELISA) (Brazil,2019). Individuals exposed to the RB51 vaccine strain are not reagent in serological tests, and direct tests (Corbel, 2006; Brasil, 2019; Hyeda 2011) are recommended.

In view of its threat to public health and the economic loss in livestock, epidemiological research of this disease is essential. Therefore, the purpose of this study was to investigate, though epidemiological inquiry and serological analysis, animal and human health related to smooth strains of Brucella spp. in a slaughterhouse situated in the Southern region of the state of Bahia, Brazil.se the paragraph as a template.

\section{Methodology}

Animal procedures were approved by the Ethical Committee for Animal Experimentation of the Universidade Estadual de Santa Cruz (UESC), under protocol 018/18. Together with the State Inspection Service (Serviço de Inspeção Estadual - SIE) five visits were carried out in order to collect blood samples from bovine females aged over 24 months, slaughtered in an exclusive beef slaughterhouse. During the time the survey was being carried out (February 14 to June 31, 2019), around 2000 animals were slaughtered per month. At each visit, an average of 40 blood samples was collected in a tube without anticoagulant, immediately after bleeding.

A total of 179 blood samples were collected, these were cooled and transported to the Microbiology Laboratory of UESC within 6 hours. Then, the samples were centrifuged and the serum was recovered and kept in microtubes at $0{ }^{\circ} \mathrm{C}$. At the Instituto Biológico de São Paulo, RBT, 2ME and CFT tests were performed following instructions from the Ministry of Agriculture, Livestock and Supply (Ministério da Agricultura, Pecuária e Abastecimento - MAPA) (Brazil, 2017b).

The procedures involving humans were approved by the Research Ethics Committee of UESC under protocol 2.836.725. Approximately 20 days after the last collection of animal samples, all slaughterhouse workers were asked to take part in a serum- epidemiological inquiry for brucellosis. They were oriented as to all procedures that would be performed, enlightened about the risks and benefits of their participation in this research and informed about the occupational effects and the significance of brucellosis in public health. An Informed Consent Form was signed by 41 workers who agreed to take part in the survey. The blood collection on these workers was done by a nurse, following all ethical norms, and the epidemiological inquiry was carried out by a veterinarian and a veterinary student.

All human samples were identified and sent to the Special Public Health Service (Serviço Especial de Saúde Pública SESP) of Itabuna, where the serum collection was performed in duplicate. One sample of serum (1 mL) from each participant was sent to a private clinical analysis laboratory (Hermes Pardini ${ }^{\circledR}$ ) for performing standard tube (SAT), since the official 
results needed to be laid out by a biomedical specialist. The remaining aliquots were transported to the UESC, frozen and subsequently tested through RBT, in accordance to MAPA instructions (Brazil, 2017b).

The epidemiological data and serological results from humans and cattle were initially stored in the Excel spreadsheet program. To perform epidemiological analysis both confirmatory tests (2ME and CFT) were considered gold standard. Then, both (the screening test and each confirmatory test individually) were compared to the gold standard. True and false positives and true and false negatives were calculated. Subsequently, the Open Epi version 3.01 was used to calculate sensitivity, specificity, positive predictive value (PPV), negative predictive value (NPV) and Cohen's Kappa coefficient, the latter to verify agreement between tests. The data related to risk factors for slaughterhouse workers was analyzed by Odds ratio and Fisher exact test with a 0.05 level of significance, both using the Open Epi program.

\section{Results}

A total of 179 samples of cattle serum belonging to females, aged over 24 months and unvaccinated against brucellosis were evaluated. The sampled animals were from Floresta Azul (25), Itororó (15), Itapetinga (15), Firmino Alves (10), Ibicuí (27), Itapebí (10), Itajú do Colônia (21), Itagimirim (46) and Potiraguá (10). All of these municipalities are located in the state of Bahia, Brazil (Figure 1), more precisely in the South-Central mesoregion, which contributed 67 samples, and the South mesoregion, which housed 112 animals (Table 1).

All samples were submitted to RBT and 2ME and CFT confirmatory tests. Of the tested animals, 39/179 (21.8\%) were reagent in the screening test and 25/179 (14.0\%) tested positive in both confirmatory tests (Table 2). The South-Central mesoregion showed 10/67 (14.9\%) animals testing positive, while in the South mesoregion the number of animals testing positive was 15/112 (13.4\%) after confirmatory tests (Table 1). 
Figure 1: Geographical location of origin of the cattle investigated according to municipalities of origin and respective mesoregions in the state of Bahia, Brazil. Source: prepared by the author using Qgis software version 3.4.

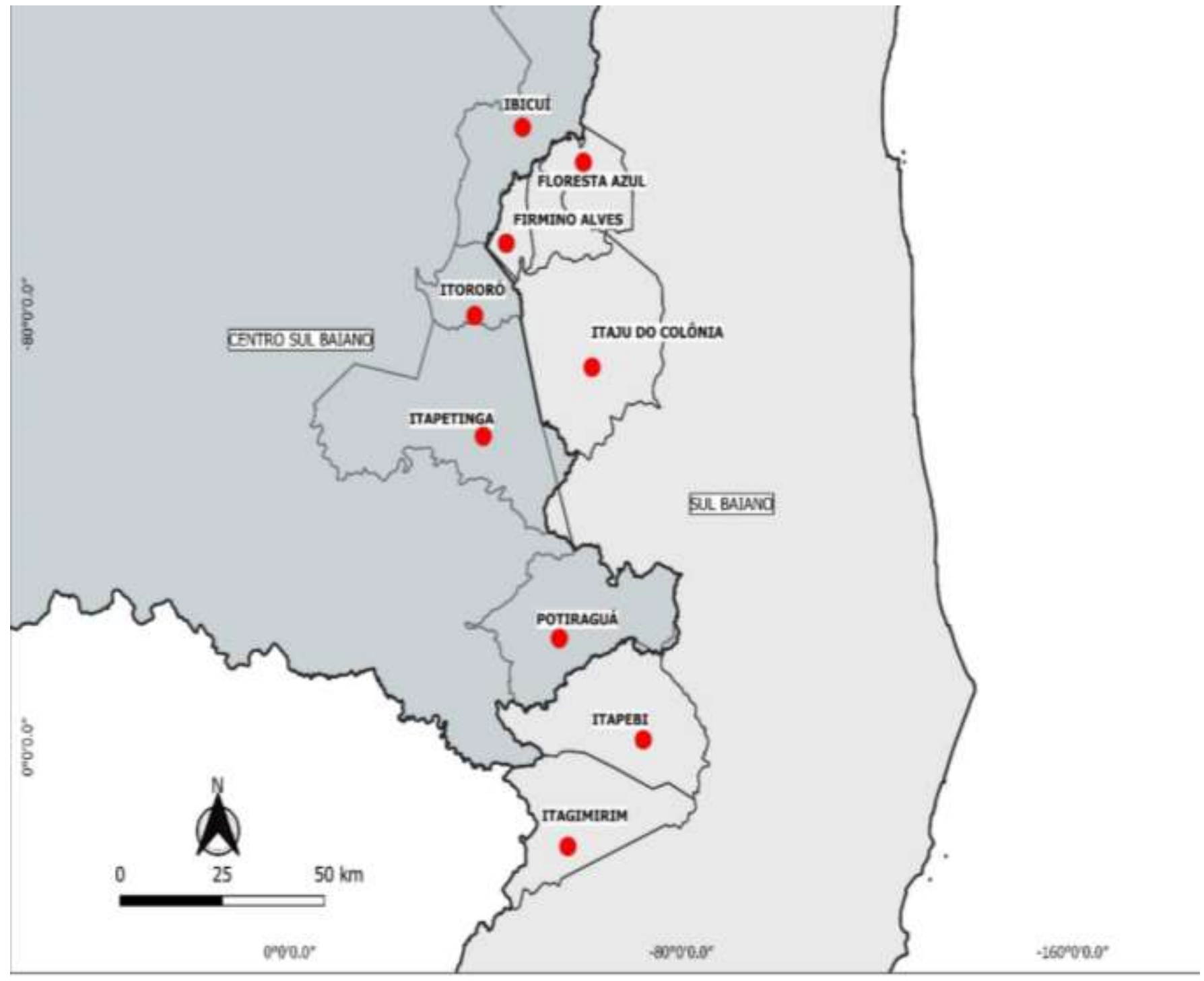

Source: Authors.

Table 1: Number and percentage of cattle positive for brucellosis in 2ME and CFT by mesoregion and city of origin.

\begin{tabular}{|c|c|c|c|}
\hline Mesoregion & City & Positive (\%) & Total \\
\hline \multirow{5}{*}{ South-Central } & Ibicuí & $3(11.1 \%)$ & 27 \\
\hline & Itororó & $1(6.6 \%)$ & 15 \\
\hline & Itapetinga & $3(20.0 \%)$ & 15 \\
\hline & Potiraguá & $3(30.0 \%)$ & 10 \\
\hline & & $10(14.9 \%)$ & 67 \\
\hline \multirow{6}{*}{ South } & Itagimirim & $1(2.2 \%)$ & 46 \\
\hline & Itapebí & $1(10.0 \%)$ & 10 \\
\hline & Itajú do Colônia & $4(19.0 \%)$ & 21 \\
\hline & Firmino Alves & $1(10.0 \%)$ & 10 \\
\hline & Floresta Azul & $8(32.0 \%)$ & 25 \\
\hline & & $15(13.4 \%)$ & 112 \\
\hline \multicolumn{2}{|l|}{ Total } & $25(14.0 \%)$ & 179 \\
\hline
\end{tabular}

Source: Authors. 
The confirmatory tests, namely $2 \mathrm{ME}$ and CFT, showed maximum Kappa coefficient $(1,0)$, indicating total agreement and, consequently, 100\% sensitivity and specificity when compared. The comparison of RBT with both confirmatory tests as gold standards demonstrated $100 \%$ sensitivity, $90.91 \%$ specificity, $64.1 \%$ positive predictive value and $100 \%$ negative predictive value (Table 2).

Table 2: Serum diagnosis of brucellosis of cattle slaughtered in Southern Region of state of Bahia, Brazil.

\begin{tabular}{|c|c|c|c|c|c|c|c|c|}
\hline Diagnostic test & Result & Samples & Frequency $\%$ & Sensitivity & Specifity & PPV & NPV & Карра \\
\hline RBT & $\begin{array}{l}\text { Reagent } \\
\text { Non reagent }\end{array}$ & $\begin{array}{l}39 \\
140\end{array}$ & $\begin{array}{l}21.8 \% \\
78.2 \%\end{array}$ & $100 \%$ & $90,91 \%$ & $64 \%$ & $100 \%$ & 0,7364 \\
\hline $2 \mathrm{ME}$ & $\begin{array}{l}\text { Positive } \\
\text { Negative }\end{array}$ & $\begin{array}{l}25 \\
154\end{array}$ & $\begin{array}{l}14.0 \% \\
86.0 \%\end{array}$ & $100 \%$ & $100 \%$ & $100 \%$ & $100 \%$ & 1 \\
\hline CFT & $\begin{array}{l}\text { Positive } \\
\text { Negative }\end{array}$ & $\begin{array}{l}25 \\
154\end{array}$ & $\begin{array}{l}14.0 \% \\
86.0 \%\end{array}$ & $100 \%$ & $100 \%$ & $100 \%$ & $100 \%$ & 1 \\
\hline Total & & 179 & $100 \%$ & - & - & - & - & - \\
\hline
\end{tabular}

Sensitivity, specificity, positive predictive value (PPV), negative predictive value (NPV), and Kappa coefficient of diagnostic tests of brucellosis calculated using OpenEpi software version 3.0. Frequency data based on sampling of 179 as 100\%. Source: Authors.

Regarding the epidemiological survey and serological results of the 41 workers from the slaughterhouse, one of them was reagent in RBT and positive for brucellosis in SAT, and ELISA detected IgG. Based on answers obtained in the epidemiological inquiry, the Odds ratio was calculated, but it was not statistically significant in any category (p > 0.05). As regards the importance of answers referring to the disease transmission path, they have been described in Table 3.

Table 3: Evaluation of risk factors related to brucellosis in workers of a slaughterhouse.

\begin{tabular}{|c|c|c|c|c|c|}
\hline Category & Exposed & Affected & $\begin{array}{c}\text { Frequency } \\
\text { ff exposed }(\%)\end{array}$ & Odds ratio & $\mathrm{P}$ \\
\hline Performs function of butcher and farmer & 8 & 0 & 19.5 & NA & - \\
\hline $\begin{array}{l}\text { Performs administrative function in the area or works } \\
\text { in external area of slaughterhouse }\end{array}$ & 5 & 0 & 12.2 & NA & - \\
\hline Always worked as butcher & 26 & 1 & 63.4 & 1,23 & 0,6837 \\
\hline Already had contact with birth remains or abortion of domestic animals & 18 & 0 & 43.9 & NA & - \\
\hline Has direct contact with blood of domestic animals & 35 & 1 & 85.4 & 0,4 & 0,4524 \\
\hline Has indirect contact with blood of domestic animals & 5 & 0 & 12.2 & NA & - \\
\hline Have already performed vaccination against brucellosis & 7 & 0 & 17.1 & NA & - \\
\hline Have already consumed unboiled or unpasteurized milk & 20 & 1 & 48.8 & 2,2 & 0,4829 \\
\hline $\begin{array}{l}\text { Have already consumed dairy products made with unboiled } \\
\text { or unpasteurized milk }\end{array}$ & 31 & 1 & 75.6 & 0,7 & 0,6155 \\
\hline Have already consumed undercooked beef & 30 & 0 & 73.2 & NA & - \\
\hline
\end{tabular}

Odds ratio calculated in software Open Epi version 3.0, verified through Fisher exact test. *NA: not applicable. Source: Authors. 
During the epidemiological inquiry and before the blood sample collection, the individual found positive for brucellosis reported chronic joint pain, but dismissed fever episodes, sweating and reproductive dysfunction.

\section{Discussion}

The PNCEBT was created in 2001 and since then has gone adapting according to evolution of the disease in the country. In spatial and temporal studies of brucellosis carried out in Brazil between 2014 and 2018, 19,631 cattle tested positive, with incidence among 0.03 and 33.93/100,000 animals (Ribeiro, 2020). This research shows the occurrence of the disease in Brazil and indicates the need for improvement in controlling it.

In this study, $14.0 \%$ of sampled animals tested positive for brucellosis. These animals were selected from several different farms in the Southern Region of the state of Bahia and this number was found in only one slaughterhouse in the region. It is noteworthy that the products from this slaughterhouse qualify for the State Inspection Service (SIE) label, which allows the product to be marketed throughout the state, thus posing a threat to the population through contaminated animals.

The prevalence of brucellosis in the Southern region of Bahia was $0.86 \%$, represented by 36 out of 3,565 females that tested positive (Alves, 2009). The higher proportion of animals testing positive during this study may be a consequence of the number of discarded animals in the slaughterhouse. It is widely known that reproductive problems are one of the main reasons for discarding dairy cattle (Ribeiro, 2003). Although the purpose of this study was not the identification of the prevalence of brucellosis, the high proportion of animals testing positive, especially in some cities, points to the need for further studies on this subject.

According to the Regulation of Industrial and Sanitary Inspection of Products of Animal Origin (Regulamento da Inspeção Industrial e Sanitária de Produtos de Origem Animal - RIISPOA) (Brazil, 2017c) animals bred for milk and meat production must be monitored for brucellosis and, in the case of animals testing positive, they must be euthanized or slaughtered in an authorized slaughterhouse. However, it can be assumed that diagnosis frequency is insufficient, since the animals that tested positive were routed and received by the slaughterhouse without any indication of positive reaction to brucellosis.

The RIISPOA provides for the release of carcasses for consumption of animals that are positive for brucellosis in the absence of indicative lesions. The regulation also provides, that if this is the case, the udder, genital tract and blood should be condemned (Brazil, 2017c). However, a previous study performed by De Macedo ( 2019) demonstrated Brucella spp. in bursitis lesions in some animals. It should be noted that bursitis is not a typical sign of brucellosis and is not included in the RIISPOA. Therefore, these animals are not condemned in the slaughter line and may pose a risk of contamination to the population.

The first paragraph of the aforementioned RIISPOA (Brazil, 2017c) article states that animals with brucellosis must be slaughtered separately. Reagent and non-reagent animals investigated in this study passed through the slaughter line in a concomitant period. This is a non-conformity to regulation, which probably occurred due to lack of awareness of the serological condition for brucellosis in these animals.

According to the PNCEBT, all cows should be vaccinated against brucellosis (Brazil, 2017a) this was not done on the 179 animals assessed in this study. This revealed a double flaw: in the inspection of farms, where vaccination is not carried out, and in the inspection of slaughterhouses, where unvaccinated animals are accepted. These inspection failures increase the risk of contamination for the population resident in Bahia and favor the continuity of bacteria in the environment.

The 2ME and CFT confirmatory tests showed maximum agreement in this study, detecting the same animals as positive. In a previous study, Meirelles-Bartoli \& Mathias (2010) found a Kappa coefficient of 0,86 for these tests. The 
efficacy of both confirmatory tests has already been proven in vaccinated and unvaccinated animals (Paulin, 2002). Beyond that, the reliability of results is higher when serology is performed by two confirmatory tests concomitantly (Meirelles-Bartoli $\&$ Mathias, 2010). On the other hand, RBT showed $100 \%$ sensitivity and negative predictive value in this study, which are desirable characteristics for a screening test.

Regarding risk factors, $48.8 \%$ of workers claim to have consumed raw milk, $75.6 \%$ have already consumed products made from unpasteurized milk and $73.2 \%$ have already eaten undercooked meat. This behavior is worrying because it increases the risk of transmission of brucellosis and other zoonoses. In a previous study, DNA from Brucella spp. was identified by PCR in 10 samples of unpasteurized milk out of 80 tested, confirming the risk factor (Paula, 2015).

As to contact with infectious sources, $85.4 \%$ are in direct contact with bovine blood, while $43.9 \%$ have already handled birth or abortion remains of domestic animals. Fetal remains, placenta and aborted fetuses of infected animals can contain the bacteria and be an important reservoir (Antoniassi 2017). As regards to inhalation as a route of transmission (Corbel, 2006) individuals exposed to this factor are more likely to be infected (Skendros, 2013), especially in slaughterhouses which are closed locations with reduced air circulation.

In addition, it was found that $63.4 \%$ of workers act professionally only at slaughterhouses, while $19.5 \%$ also perform some livestock activity and $17.1 \%$ have already vaccinated animals against brucellosis. According to MAPA standards, vaccination against brucellosis is to be performed by veterinarians holding Official Veterinary Service authorization and assistant vaccinators are to be previously trained and registered (Brazil, 2017d). In this study, the workers acting as vaccinators did not mention any training. Performing vaccination against brucellosis without procedural knowledge increases the accident risk factor. It is a well-documented fact that these accidents can occur even with authorized professional workers and may result in infection (Brazil, 2019).

Despite the importance of risk factors, no association was found between exposure and the occurrence of human brucellosis, and the Odds ratio was also not significant, $p>0,05$. It is worth mentioning that the number of volunteers in this study was not high, which may explain the absence of association. However, the biological character of the data reinforces the relevance of discussing the values found. Note that one volunteer (2.4\%) submitted to at least four risk factors tested positive for brucellosis in this study. Of these risk factors, some, such as direct contact with animals and consumption of raw milk and its derivatives, are often related in infected individuals (Soares, 2015). This data stresses the importance of educational measures for the population at risk.

\section{Conclusion}

Infection from smooth strain Brucella spp. was found in cattle slaughtered in the slaughterhouse studied. The seropositivity of one individual for brucellosis, associated to the epidemiological data suggests that the disease is present and may be explained through exposure of workers to Brucella spp. in slaughterhouses, of occupational origin, and because of educational and cultural habits, due to lack of information or consumption of potentially contaminated food. Therefore, the data alert as to the occurrence of brucellosis among both animals and humans, reinforces the need for measures to be taken towards prevention, education, and control in order for the country to achieve eradication and promote public health development as proposed by the PNCBET.

The exposed study reinforces the debate on preventive health and the discussion on neglected zoonoses; as well as stimulating research for deeper epidemiological and microbiological research. 


\section{References}

Alves, A. J. S., Gonçalves, V. S. P., Figueiredo, V. C. F. D., Lôbo, J. R., Bahiense, L., Amaku, M., \& Dias, R. A. (2009). Situação epidemiológica da brucelose bovina no Estado da Bahia. Arquivo Brasileiro de Medicina Veterinária e Zootecnia, 61, 6-13. https://doi.org/10.1590/S0102-09352009000700002

Antoniassi, N. A. B., Juffo, G. D., Pescadora, C. A., Corbellini, L. G., Sonne, L., Gomes, M. J. P., \& Driemeier, D. (2016). Ocurrence and caracterization of bovine abortion caused by Brucella abortus infection in southern Brazil. Archivos de Medicina Veterinaria, 48(1), 43-49. 10.4067/S0301$732 \mathrm{X} 2016000100006$

Brasil. Ministério da Agricultura Pecuária e Abastecimento. (2017a) Programa Nacional de Controle e Erradicação da Brucelose e da Tuberculose Animal (PNCEBT).

Brasil. Ministério da Agricultura Pecuária e Abastecimento. (2017b) IN 34, de 9 de setembro de 2017 Requisitos para diagnóstico de brucelose por laboratórios da Rede Mapa.

Brasil. Ministério da agricultura pecuária e abastecimento. (2017c) Decreto $\mathrm{N}^{\circ} 9.069$, de 31 de março de 2017 dispõe sobre o regulamento da inspeção industrial e sanitária de produtos de origem animal (RIISPOA).

Brasil. Ministério da Agricultura Pecuária e Abastecimento. (2017d) Instrução Normativa SDA 10, de 3 de Março De 2017. Capítulo III que dispões acerca da Vacinação Contra a Brucelose.

Brasil. Ministério da Saúde. (2019) Secretaria de Vigilância em Saúde. Protocolo Estadual de Brucelose Humana: Manejo clinico e vigilância em saúde. Núcleo de Comunicação DIVE/SC.

Corbel, M. J. (2006). Brucellosis in humans and animals. World Health Organization. https://apps.who.int/iris/handle/10665/43597

de Macedo, A. A., Galvão, N. R., Sá, J. C., da Silva, A. P. D. C., da Silva Mol, J. P., Dos Santos, L. S., \& de Carvalho Neta, A. V. (2019). Brucella-associated cervical bursitis in cattle. Tropical animal health and production, 51(3), 697-702. https://doi.org/10.1007/s11250-018-1745-X

Emy, K. S., Misaco, W., Chusniati, S. \& Maslachah, L. (2018) Isolation and identification of Brucella suis in pigs as zoonotic disease in endemic areas of east Java, Indonesia. African Journal of Infectious Diseases; 12(1), 148-51. 10.2101/Ajid.12v1S.22

Foster, G., Osterman, B. S., Godfroid, J., Jacques, I., \& Cloeckaert, A. (2007). Brucella ceti sp. nov. and Brucella pinnipedialis sp. nov. for Brucella strains with cetaceans and seals as their preferred hosts. International journal of systematic and evolutionary microbiology, 57(11), 2688-2693. 0.1099/ijs.0.65269-0

Hyeda, A., \& Sbardellotto, F. Exposição acidental à vacina da brucelose. https://cdn.publisher.gn1.link/rbmt.org.br/pdf/v9n2a02.pdf

Jahans, K. L., Foster, G., \& Broughton, E. S. (1997). The characterisation of Brucella strains isolated from marine mammals. Veterinary microbiology, 57(4), 373-382. https://doi.org/10.1016/S0378-1135(97)00118-1

Kang, Y. S., Brown, D. A., \& Kirby, J. E. (2019). Brucella neotomae recapitulates attributes of zoonotic human disease in a murine infection model. Infection and immunity, 87(1). https://doi.org/10.1128/IAI.00255-18

Meirelles-Bartoli, R. B., \& Mathias, L. A. (2010). Estudo comparativo entre os testes adotados pelo PNCEBT para o diagnóstico sorológico da brucelose em bovinos. Arquivos do Instituto Biológico, 77(1), 11-17. https://doi.org/10.1590/1808-1657v77p0112010.

Mühldorfer, K., Wibbelt, G., Szentiks, C. A., Fischer, D., Scholz, H. C., Zschöck, M., \& Eisenberg, T. (2017). The role of 'atypical'Brucella in amphibians: are we facing novel emerging pathogens? Journal of applied microbiology, 122(1), 40-53. 10.1111/jam.13326

Osterman, B., \& Moriyon, I. (2006). International committee on systematics of prokaryotes; subcommittee on the taxonomy of Brucella: minutes of the meeting, 17 September 2003, Pamplona, Spain. International journal of systematic and evolutionary microbiology, 56(5), 1173-1175. https://doi.org/10.1099/ijs.0.64349-0

Paula, C. L. D., Mioni, M. D. S. R., Appolinário, C. M., Katayama, E. R., Allendorf, S. D., \& Megid, J. (2015). Detection of Brucella spp. in unpasteurized cow milk by polymerase chain reaction (PCR). Arquivos do Instituto Biológico, 82. http://dx.doi.org/10.1590/1808-1657000252013

Paulin, L. M., Prado, G. E. S., Federsoni, I. S. P., Teixeira, A. C., Castro, V., \& Genovez, M. E. (2002). Estudo comparativo dos testes 2-mercaptoetanol e reação de fixação do complemento no sorodiagnóstico da brucelose bovina. Arquivos do Instituto Biológico, 69(4), 41-47. http://www.biologico.sp.gov.br/uploads/docs/arq/V69_4/paulin.pdf

Petry, A. C., Castro, B. G., \& Freitas, F. (2019). Research of antibodies anti-Brucella abortus e anti-Brucella canis in dogs domiciled in dairy farms in the medium-north region of Mato Grosso. Scientific Electronic Archives, 12(2), 114-117. https://doi.org/10.36560/1222019636

Ribeiro, A. C., McAllister, A. J., \& Queiroz, S. A. D. (2003). Effect of culling reasons on lifetime profitability measures of dairy cows in Kentucky. Revista Brasileira de Zootecnia, 32(6), 1737-1746. https://doi.org/10.1590/S1516-35982003000700025

Ribeiro, C. M., de Carvalho, J. L. B., de Santis Bastos, P. A., Mendes, R. G., Katagiri, S., \& da Costa, V. M. (2020). Spatial and temporal trend analysis of bovine brucellosis in Brazil, 2014 to 2018. Semina: Ciências Agrárias, 41(4), 1279-1290. http://dx.doi.org/10.5433/1679-0359.2020v41n4p1279

Rónai, Z., Kreizinger, Z., Dán, Á., Drees, K., Foster, J. T., Bányai, K., ... \& Gyuranecz, M. (2015). First isolation and characterization of Brucella microti from wild boar. BMC veterinary research, 11(1), 1-6. https://doi.org/10.1186/s12917-015-0456-Z

Schneider, R. C., Santos, M. D., Lunardi, M., Benetti, A. H., Camargo, L. M., Freitas, S. H., \& Costa, D. S. (2013). Prevalence of brucellosis and risk factors associated with its transmission to slaughterhouse employees in the Cuiaba metropolitan area in the state of Mato Grosso. Semina: Ciências Agrárias, 34(5), 2367-2373. 10.5433/1679-0359.2013v34n5p2367 
Research, Society and Development, v. 10, n. 3, e39710313248, 2021

(CC BY 4.0) | ISSN 2525-3409 | DOI: http://dx.doi.org/10.33448/rsd-v10i3.13248

Scholz, H. C., Hofer, E., Vergnaud, G., Fleche, P. L., Whatmore, A. M., Dahouk, S. A., \& Tomaso, H. (2009). Isolation of Brucella microti from mandibular lymph nodes of red foxes, Vulpes vulpes, in lower Austria. Vector-borne and zoonotic diseases, 9(2), 153-156. 10.1089/vbz.2008.0036

Scholz, H. C., Hubalek, Z., Sedláček, I., Vergnaud, G., Tomaso, H., Al Dahouk, S., \& Nöckler, K. (2008). Brucella microti sp. nov., isolated from the common vole Microtus arvalis. International journal of systematic and evolutionary microbiology, 58(2), 375-382. 10.1099/ijs.0.65356-0

Scholz, H. C., Nöckler, K., Göllner, C., Bahn, P., Vergnaud, G., Tomaso, H., \& De, B. K. (2010). Brucella inopinata sp. nov., isolated from a breast implant infection. International journal of systematic and evolutionary microbiology, 60(4), 801-808. 10.1099/ijs.0.011148-0

Skendros, P., \& Boura, P. J. R. S. T. (2013). Immunity to brucellosis. Revue scientifique et technique (International Office of Epizootics), 32(1), 137-147. 10.20506/rst.32.1.2190

Soares, C. D. P. O. C., Teles, J. A. A., Santos, A. F. D., Silva, S. O. F., Cruz, M. V. R. A., \& Silva-Júnior, F. F. D. (2015). Prevalencia de la Brucella spp en humanos. Revista latino-americana de enfermagem, 23(5), 919-926. https://doi.org/10.1590/0104-1169.0350.2632.

Tortora, G. J., Funke, B. R., case, C.L. (2012). Microbiologia. (10a ed.), artmed, 934p.

Whatmore, A. M., Davison, N., Cloeckaert, A., Al Dahouk, S., Zygmunt, M. S., Brew, S. D., \& Schlabritz-Loutsevitch, N. E. (2014). Brucella papionis sp. nov., isolated from baboons (Papio spp.). International journal of systematic and evolutionary microbiology, 64(Pt 12), 4120. 10.1099/ijs.0.065482-0

Zygmunt, M. S., Jacques, I., Bernardet, N., \& Cloeckaert, A. (2012). Lipopolysaccharide heterogeneity in the atypical group of novel emerging Brucella species. Clinical and Vaccine Immunology, 19(9), 1370-1373. 10.1128/CVI.00300-12 